\title{
Social-Ecologic Oriented Curricula in Engineering Education: "Leonardo's Oath" as an Answer to Janus-Headedness in Engineering Work
}

Original article

DOI: 10.31992/0869-3617-2021-30-1-115-124

Ralph Dreher - PhD, Prof., Chair for Didactics of Technical Vocational Education, dreher.tvd@ uni-siegen.de

University of Siegen, Germany

Address: 11, Breite Strasse, Siegen, 57076, Germany

Vladimir V. Kondratyev - Dr. Sci. (Education), Prof., Director of the Centre for Professional Training and Advanced Retraining for Educators, Head of the Department of Methodology of Engineering Activity, vvkondr@mail.ru

Maria N.Kuznetsova - Cand. Sci. (Education), Assoc. Prof., the Department of Foreign Languages in Professional Communication,7mashulka@mail.ru

Kazan National Research Technological University, Tatarstan, Russia

Address: 68, K. Marx str., Kazan, 420015, Russian Federation

Abstract. Any engineering activity is characterized by contradictions: social - between engineering problems and technical solutions and technological - between laws of nature and artificial engineering objects. This leads to the ethical dilemma of engineering work: when creating something new, social and environmental problems usually arise. This explains the "Janus-headedness" of the engineering profession: although the original intention is to do good, however, there are negative consequences that must be mitigated through new technical solutions that have the effect of creating improvements. "Leonardo's oath" not only highlights this need, but also serves as a reference point for developing the engineering training programs which should be prepared specifically for this task. As a starting approach, the article suggests using the "sustainability triangle" - a model of social transformational effects in relation to the definition of the variables "social", "economy" and "ecology" and their corresponding interdependence. It is shown that digitalization changes the "economy" setting in the sustainability triangle, which inevitably leads to consequences for the currently dependent variables "social " and "ecology". Digitalization requires, first, an economic approach, not environmental. It does not solve the fundamental problem: participation in the formation of a society to achieve socio-ecological balance is faced with the duality between the ethical necessity of forming and lack of real balance.

Keywords: acceptance of technology, constructivism, design work, Leonardo's oath, engineering sciences

Cite as: Dreher, R., Kondratyev, V.V., Kuznetsova, M.N. (2021). Social-ecologic Oriented Curricula in Engineering Education: "Leonardo's Oath" as an Answer to Janus-Headedness in 
Engineering Work. Vysshee obrazovanie v Rossii = Higher Education in Russia. Vol. 30, no. 1. pp. 115-124, doi: 10.31992/0869-3617-2021-30-1-115-124. (In Russ., abstract in Eng.)

\section{Социально-экологически ориентированные учебные планы: "Клятва Леонардо" как ответ на двуликость Януса в инженерном деле}

Научная статья

DOI: 10.31992/0869-3617-2021-30-1-115-124

Apeер Ральф - PhD, проф., зав. кафедрой дидактики профессионально-технического образования, dreher.tvd@uni-siegen.de

Университет Зигена, Германия

Aдрес: 11, Breite Strasse, Siegen, 57076, Германия

Кондратьев Владимир Владимирович - А-р пед. наук, проф., директор Центра подготовки и повышения квалификации преподавателей вузов, зав. кафедрой методологии инженерной деятельности, vvkondr@mail.ru

Кузнецова Мария Николаевна - канд. пед. наук, доцент, 7mashulka@mail.ru

Казанский национальный исследовательский технологический университет, Татарстан, Россия Адрес: 420015, г. Казань, ул. К. Маркса, 68

Аннотация. Аюбая инженерная деятельность характеризуется диалектическими противоречиями: социальными - между инженерными проблемами и техническими возможностями их решения, а также технологическими - между естественными законами природы и искусственными инженерными объектами. В статье показано, что это приводит к этической дилемме инженерной работы: при создании чего-то нового возникают, как правило, социально-нравственные и экологические проблемы. Это объясняет «двуликость Януса» в инженерной профессии: при изначальном намерении делать добро, тем не менее, возникают негативные последствия, которые должны быть смягчены через новые технические решения. «Клятва Иеонардо» не только подчёркивает это обстоятельство, но и выступает в качестве ориентира для разработки инженерных учебных программ, с тем чтобы они также разрабатывались специально для решения этой задачи. В качестве исходного подхода в статье предлагается использовать «треугольник устойчивости» - модель социальных трансформационных эффектов в отношении определения переменных «социальное», «экономика» и «экология» и их соответствующей взаимозависимости. Цифровизация требует прежде всего экономического, а не экологического подхода и потому не решает фундаментальной проблемы: участие в формировании общества с целью достижения социально-экологического баланса сталкивается с двойственностью между этической необходимостью формирования баланса и невозможностью его реального достижения.

Ключевые слова: инженерная деятельность, конструктивизм, учебные планы, проектные работы, «клятва $\Lambda$ еонардо», инженерные науки

Аля цуитирования: Dreher, R., Kondratyev, V.V., Kuznetsova, M.N. Social-ecologic Oriented Curricula in Engineering Education: "Leonardo's Oath" as an Answer to Janus-Headedness in Engineering Work // Высшее образование в России. 2021. Т. 30. № 1. С. 115-124. DOI: 10.31992/0869-3617-2021-30-1-115-124. 


\section{What does "Janus-Headedness" mean?}

The following is based on the thesis that engineering work is fundamentally characterized by an ethical dilemma:

- on one hand, the results of engineering work influence our lives like hardly anything has done before, because neither modern medical diagnostics nor global multimedia communication nor the possibilities by which the connection of private and working life can be shaped by mobility offers are conceivable without prior engineering work;

- on the other hand, the format of work, i.e. what we work with and how we work, is directly influenced in an industrially shaped society by the possibilities created and the predetermined technical prerequisites, which in turn leads to a constant change of professions: anyone who was a specialist in machining technology who was able to operate a lathe with precision using his highly developed motor skills must now be able to manage and edit data packages for controlling the machine and will, in future, train expert systems which in turn automatically determine machine use and production data.

The above example of changing professions already gives an indication as to where the ethical dilemma of engineering work arises [1]. Thus, to create something new with good intentions (efficient production processes, focused use of resources by reducing scrap production, demand-based production without production surpluses), a concurrent follow-up effect commences, which in turn raises a significant number of questions: Who can do that? What happens to those who are unable to keep up? Where does the right of the engineer to radically change the content of work and thus to intervene in the content of life and life plans come from?

Engineering work in particular is therefore characterized by a high design potential, which also means that whoever designs make settings [2]. And these settings, in turn, have consequences for people and the environment, resulting in the Janus-headedness of the engineering profession: with the intention of doing good, consequences nevertheless arise which must be endured and mitigated - through new technical solutions, which in turn have the effect of generating improvements and consequences.

\section{No decision: the "non-moralistic engineer"}

It can actually be said that engineering work often relies on the fact that the result of the work is only one potential possibility - the engineer does not even get to decide on its use. For this reason, conceptual engineering work is primarily "non-moralistic", i.e. it is limited to proof of viability. Let us assume this position as an example with the CDIO approach, which reduces engineering work to the phases of designing (planning, drawing, algorithms), implementing (manufacturing, coding, testing validation), operating (servicing evolving) and conceiving (customer needs, technical/regulation concept, business plan) and thus does not explicitly(!) take into account the perspective effects of design work in either the ecological or social dimensions [3, p. 26].

A reason that is frequently cited within engineering didactics is that application-oriented engineering work, i.e. the actual creation of a product or the provision of a service, is always preceded by a discursive process, at the end of which the decision for realization was made - this also removes the need for the engineer to evaluate his work ethically. Both these assumptions must be considered as being essentially incorrect:

1. The effects of the concept can be so extensive that the engineer may still have a broad overview of them though this will never be comprehensive.

Here an example is provided: the architects and creators of the social media outlets had the vision, through more communication, of a society growing together. Consequently, they did not employ any means of control - and thus, in so doing, they created a portal for hate speech. As it was specifically their goal to create meaningful user interfaces for everyone, they had to be aware that everyone would use it for their own purposes. Conversely, wider "society" with its intended role as a controlling authority, was not aware for a long time that social-media was striving for precisely this opening of powerful communication 
channels in the sense of opinion-forming communication channels; society believed in expert tools in the hands of a few. Mutual speechlessness, resulting from a lack of interest in communication on the part of engineers and the social inability to communicate about it, thus undermines social control over these communication systems - and turns them into powerful tools of neo-dictatorial political systems.

2. The previously diagnosed lack of interest on the part of engineers in communicating about their own design work is often justified with the argument of "technically sweet": everything that is feasible will at least be conceptualized in engineering science, with which investors will then also be brought into play. Since I consider myself morally impeccable as an engineer, it is therefore much better for me to do it and retain control of the concept and realization than someone else.

It was with this very argument that Robert Oppenheimer defended his work and the work of his team (and therefore of the engineers involved) in the construction of the hydrogen bomb. According to him, it was clear to him that the basic functioning of such a bomb was clear to many - but not yet the actual functioning of the construction. So, a feasible concept had to be formulated and then actually realized. And, as long as he did not accuse himself and his clients of having any dishonorable intentions, it was clear to him: "As long as my team is the first to realize the thinkable and feasible, the technically sweet, it will remain sweet because it can be controlled. The possibility that others in completely different settings would do the same thing yet with the same justification and thus the arms race would "only" reach a new level overall, but would not end the principle of deterrence, he did not see, could not see, no one wanted to make available to him as an adequate discursive level of reflection"1.

1 To understand the meaning of the phrase "technically sweet" see: Robert OppenheimerVater der Bombe? Available at: https://www. menscheinstein.de/biografie/biografie_jsp/ key $=1542 . h t m l$ (accessed 10.12.2020).
These two examples above demonstrate that retaining control over technical developments and their related consequences is a task that is as necessary as it is difficult. Firstly, it must be stated that the person who creates must also actively participate in shaping this process. Engineers, like doctors, have the task of justifying their actions in a self-determined and external manner. Selfdetermined by a work ethic conveyed to them as part of "engineer-pedagogical education", externally determined by active participation in social discourse through complete (meant in the sense of presenting the maximum possible overview from their perspective) disclosure of the overall effect of their conception and realization work. Instead of waiting to see whether social doubts or even resistance will ensue, it is important to take the initiative and demand the necessary dialogue to ensure one's own security.

\section{"Leonardo's Oath"}

The previous examples illustrate that doing engineering work not only means taking on a high degree of responsibility for the functioning of a technical system, but also simultaneously means recognizing the social (re)design potential intrinsic in technology. Moreover, it also shows that engineering work that creates technology also creates and intensifies a view of the consequences of applying technology, even if this is then also risked. To risk this, in turn, means taking responsibility, be it:

- by means of justified and widely published (and thus public) refusal of the individual to participate in the project (turning away from the principle of "technically sweet"), which s/he will in turn have to do and for which s/he will need as a precondition to be able to do so because of his/her engineering studies, or

- through "contextual follow-up", which means that it is part of engineering work to reduce the unseen consequences of the use of technology to a remainder that can be defined as harmless. This then requires that the engineers contribute to a discussion in society as a whole, in which a compromise must be found as to how to preserve what is desired and to minimize what 
is undesirable. Such a process can be observed especially in the further development of the social network, where the desire for freedom of opinion as a high social good collides with the strong mechanism of fake news, which then leads to the uncertainty as to which type of filter should warn against which posts or whether they should be deleted immediately.

"Leonardo's Oath" should not only emphasize this necessity, that especially those who initiate social design processes through their engineering work must, at the same time, also take part in the debate on this design (!), but should also act as a benchmark for engineering curricula, so that these also prepare specifically for this task. It reads:

Every study-course of Engineering must be based on the idea, that engineers will be educated to use their technical knowledge with their designresponsibility oriented towards the principles of

- ethical legitimacy,

- sustainability,

- societal checkability [4].

\section{Reflective Project Work}

as an Engineering-Pedagogical Principle

In accordance with the formulation set out above, the "Leonardo's Oath" calls for the professionalization of engineers as a core task of engineering science teaching, which must be geared towards ensuring that students are permanently given the opportunity to develop an understanding of the fact that:

- engineering work is a transformational task of technology through to engineering [5, p. 81], which undoubtedly needs to be mastered and which requires a high degree of scientific knowledge on the one hand and design knowledge for implementation on the other hand (dimensioning, production process planning);

- it is also a permanent examination of the transformational process that technology causes in society through its use (resource consumption, lifestyle, presentation of impact scenarios during use) [6].

This means that the two transformational processes must therefore not be viewed individ- ually (technology development here, technology assessment there), but rather as a joined-up process:

- at the beginning of which is a process of reflection (goal and purpose: What do I want and why?);

- followed by the assessment (conception phase through to examination of technological knowledge);

- the recognition of what is achievable (realization phase through to implementation in technology);

- the final assessment of what has been achieved, including whether and to what extent the objective, and above all the purpose, has been achieved.

\section{The "Triangle of Sustainability" as a basis for reflection}

From what is described above it is clear that engineering work means transformational work in two ways:

- on one hand, the transformation of technology, i.e. the exploitation of recognized scientific phenomena as reproducible effects into applicable technology in the form of products and services as application-oriented transformation (which corresponds to the common idea of engineering - e.g. the transformation of resistive or capacitive effects into a touchpad for smartphones), and

- on the other hand, the description of the transformation process which the application of this technology provides for society - i.e. the disclosure of both its purpose (in terms of the expected benefit) and its effect on coexistence (as regards the possible risks based on the limitation of the system) as social transformation work.

It has also already become clear that while social transformation work is as much a task of engineering as application-oriented transformation, it nevertheless seems much more difficult to accomplish it. For while application-oriented transformation engineering work can fall back on the principles of empirically supported development work (with clear parameters, results and often also interpretation procedures), it is much 
more challenging to estimate the social impact, especially since there is also a lack of a clear specification here of what is to be taken into account or where this transformational hermeneutical (!) interpretation work should be carried out.

The "Triangle of Sustainability" has established itself as an initial approach; a model of social transformation effects the authorship of which is still unclear today, but which was first used in the "Brundtland Report" with regard to the definition of the variables "social", "economy" and "ecology" and their respective interdependence [7, p. 46].

According to this idea, social, ecological and economic settings influence one other, e.g.

- an improvement in "social conditions" means both economic consequences (poorer competitiveness due to higher wages, but also rising domestic consumption) and ecological consequences (the acquisition of more sustainable products becomes possible; but at the same time, however, consumption increases with higher resource consumption and increased transport performance);

- an increased avoidance of ecological consequences results in an accompanying increase in the price of resources and products with both social consequences (reduction of the sense of prosperity/well-being through lower consumption resulting in personal demotivation) and economic effects (increased product prices reduce market opportunities, reduced product sales reduce overall economic performance);

- focusing on economic advantage in turn results in a lowering of ecological standards (with the consequence of more environmentally hostile production) as well as wage levels, or the relocation of waged labor to countries with low wage levels (with the consequence of loss of income and increased fears relating to livelihoods).

However, these considerations also show that there can be no ideal solution after this triangle, precisely because the preference for one setting always has (initially perceived as negative) effects on the other settings, which are then no longer settlings but dependent variables.

"Social transformation work" in engineering work thus means:
1) as a first step, to be able to identify and describe settlings and the resulting dependencies;

2) to establish how objective disadvantages can be absorbed and mitigated. For example, the shift from fossil fuel to renewable energy will undoubtedly mean increasing energy costs, reducing export opportunities and job losses. At the same time, however, concepts are being developed beyond the "business as usual" which is no longer considered possible, and thanks to the pioneering role, new products (solar cells, wind turbines, geothermal plants) are emerging for new export markets and with new jobs;

3) to help shape the discussion on how to manage this entire transformation process. This result is a whole bundle of questions that need to be solved in a reasonable way in the overall social discourse (although the following list does not claim to be exhaustive): What is necessary to mass produce solar cells in an ecologically acceptable way? How can wind turbines become quiet? Who is funding the social consequences of this change? Who is acting as a producer of new technologies and with what support?

The questions referred to in 3 ) show that it is only possible to answer them if the right information is provided precisely from the engineering work, e.g. regarding the possibility of realizing ecologically sound solar cells and wind turbines, the duration of the change (in combination with the question of whether an overall reduction in substitution possibilities cannot be created in parallel by reducing energy conversion into energy and the wise choice of location) or which conditions must be created for the mass production of the necessary products. It becomes clear that sound (!) engineering knowledge must be made available to the discourse of society as a whole, whereby knowledge means not only preparing facts as singularities, but above all designing scenarios as to how such change processes can be initiated and which accompanying processes are then necessary (e.g. provision of bridging aids, responsibly simplified approval procedures).

For engineering science teaching, two things follow: 
- a recognition of necessities and a personal examination of the triangle's settings (What was prioritized first and why? What follow-up processes were defined, which ones were defined and which were not and why?) presuppose that students are provided with the opportunity to work on tasks with scope for design (i.e. precisely an ambiguous solution) as projects. They must inform themselves about the task as well as plan solutions, make and justify their solutions, prove the feasibility of the solution (by simulation) and present it appropriately to the specialist and lay audience (see the principle of the holistic action [8, p. 30]);

- in addition, it is necessary to work out which secondary transformational processes result from the solution proposal and how these can be designed (as a proposal for social transformation work) by reflecting on the solutions found. The following applies here: only through this phase of reflection it is possible to actually conclude the project, since both transformational processes are now equally the subject of engineering science teaching. At the same time, this creates the more fundamental integration of engineering sciences, which has previously been recognized as necessary.

\section{A new challenge: digitalization} as a balance of social-ecologic responsibility

The examples chosen in advance were mainly the result of the desire that has shaped the past decades to set strong ecological priorities in the face of objectively recognized needs. The pursuit of "sustainability" is therefore often equated with ecologically sensible behavior or decisions that respect ecological processes [9]. The starting point in the triangle of sustainability is therefore always the setting of "ecology".

However, the trend towards the digitalization of work is now also producing a return to the "economy" setting. For digitalizing work means, first of all, making it more efficient - either by enabling people to work faster or by replacing human labor with automation (both of which in turn explain the proclamation of a new industrial revolution). An example follows here:
1. Sensors replaced a previously manually controlled bending machine, each of which noted what was being bent by the skilled workers (material, wall thickness, profile, bending radius, number of bending operations).

2. After approximately one year, the company was ready to generate a simple data pool from this data, which covers $90 \%$ of all machine applications. The machine was now equipped with actuators and could therefore be controlled automatically.

3 . In combination with a robotized feeder system, the number of workplaces could be reduced from 4 people ( 2 per shift; one responsible for the material flow, one to operate the machine) to one workplace (expert for special cases).

4. Thanks to the fact that the special cases continued to be recorded, the automation could be increased to $99 \%$, for the remaining $1 \%$ an interpolation algorithm is being worked on very successfully.

5. The machine is now regarded as a classic example of SME, how experience knowledge (in this case: the control of the machine) can be captured and algorithms can be used and is also conceivable for a variety of other sheet metal processing machines.

6. The principle that the skilled worker must necessarily give up his specialist knowledge as his capital for the labor market via the system, in order to then make himself obsolete, is described as justifiable, since this also prevents "brain drain" (i.e. someone takes his experience knowledge with him into retirement and into the grave).

Digitalization must therefore be understood as a development that first changes the setting "economy" in the triangle of sustainability which inevitably leads to consequences for the now dependent variables "social" (here: job loss) and "ecology" (here: job loss): saving of resources and energy by reducing production errors and eliminating the commute to work). The following Table 1 shows (in an incomplete yet illustrative way), which social and ecological consequences can result from which economic settings. 
Social-ecological consequences of digitalization

\begin{tabular}{|l|l|l|}
\hline \multicolumn{1}{|c|}{ Setting Economy } & \multicolumn{1}{|c|}{ Dependent variable Social } & \multicolumn{1}{c|}{ Dependent variable Ecology } \\
\hline $\begin{array}{l}\text { Takeover of process } \\
\text { control }\end{array}$ & $\begin{array}{l}\text { Elimination of simple skilled work on the } \\
\text { press controls }\end{array}$ & $\begin{array}{l}\text { Higher assured process efficiency with lower scrap } \\
\text { production and optimized energy conversion }\end{array}$ \\
\hline $\begin{array}{l}\text { Taking over process } \\
\text { decisions }\end{array}$ & $\begin{array}{l}\text { Loss of high-quality skilled work/ } \\
\text { management work }\end{array}$ & $\begin{array}{l}\text { Less machine downtime due to mutual optimal } \\
\text { utilization, at the same time, more (regional) freight } \\
\text { between production sites }\end{array}$ \\
\hline $\begin{array}{l}\text { Recognition of cus- } \\
\text { tomer needs }\end{array}$ & $\begin{array}{l}\text { Demand-oriented products with a high } \\
\text { market value; } \\
\text { Desire in the face of falling prices } \\
\text { promotes the possibility of comfort } \\
\text { shopping }\end{array}$ & $\begin{array}{l}\text { Avoidance of unnecessary overproduction, reduction } \\
\text { of production waste; } \\
\text { at the same time: reduction of product costs and } \\
\text { increase of quantities and consumption of resources } \\
\text { by turning away from the purchase for a specific } \\
\text { purpose }\end{array}$ \\
\hline $\begin{array}{l}\text { Algorithms of digital } \\
\text { processes as a competi- } \\
\text { tive feature }\end{array}$ & $\begin{array}{l}\text { Creation of new, demanding work con- } \\
\text { tent with high potential for design and } \\
\text { responsibility }\end{array}$ & $\begin{array}{l}\text { Positive effects are possible as well as negative effects } \\
\text { depending on the goals of the algorithms; }\end{array}$ \\
\hline
\end{tabular}

Table 1 shows that an increase in the efficiency of the production of goods resulting from the technical possibilities of digitalization does not necessarily mean a reduction in social and ecological standards. Instead, Table 1 shows that even that direct positive effects are likely, especially for the "ecology" variable.

What appears to be more decisive is the objective with which digitalization is pursued and which social control mechanisms are introduced for this purpose:

- for example, a price for disposal included as part of the purchase price allows for more conscious consumption without reducing the economic result and competitiveness - the product remains equally expensive, but the pleasure/comfort purchase becomes increasingly unlikely while at the same time a more direct participation of the consumer in the overall task of recycling the product at the end of the product use takes place;

- simultaneously, the increase in production efficiency through digitalization can (or better, must) be used to compensate for the inevitable reduction of jobs with previous work content, as shown in Table 1, by turning business management resources into economic resources, by financing the requalification or upgrading of skills, by the foreseeable need to restructure the education system and (compared to society as a whole) by providing adequate provision for those who do not manage this process of personal change.

Naturally, the previously mentioned design of the tax and social security system is NOT the task of engineering work - but it is an engineer's job to disclose that:

- digitalization enables added value in business management (and that this is actually achieved through functioning digitalization);

- if the algorithms are appropriately designed, it is possible to achieve ecological advantages - but also to allow for any disadvantages;

- new work processes designed from engineering work require new work contents and the elimination of old forms of skilled work, and

- it must be a task of engineering work to support these new forms of skilled work with new tools: here specifically editing and simulation tools (for generating and testing algorithms).

It becomes clear: the aim of the level of reflection in such educational processes within engineering teaching is not so much to evaluate the solutions worked out by means of the paradigm of the all-encompassing, but rather to objectify (!), which consequences arise from the respective use of technology from an engineering-scientific perspective (or precisely not in the sense of weakening prejudices about the use of technology, as is fatally occurring in the field of renewable energies with the social rejection of wind turbines, PV fields, transmission lines and the like). 
This is precisely why the following applies: that "Leonardo's Oath" should not demand the lonely decision of an individual engineer, but instead demand that the engineer, with his expertise, should participate in the social discourse about which dangers (and non-hazards, but prejudices and fears) the respective use of technology poses (or not) or which consequential problems must be solved technically: "... towards the principles of [...] ethical legitimation..." (Leonardo's Oath).

\section{Conclusion}

From the examples shown here, two challenges become apparent which engineering science teaching faces:

- The focus on a discussion about the technology in the course of the decarbonization process, which follows an ecological setting with an ecological-economic-social scheme, must be understood as a snapshot that has arisen, above all, from the technically exuberant possibilities for mobility and consumer goods production. Due to the question of the existence of planet Earth as we know it, it takes an absolutely priority position but it is not singular, because: the possibilities of machine-supported process control triggered by digitalization lead to the economic-social-ecological setting. For this process leads not only to the automation of work but also to the automation of publication and thus influences the process of social opinion-forming, precisely because it makes it possible to disseminate news and fake news, funny, racist and sexist memes, fact-oriented and reality-distorting blogs and chats.

- The idea underlying the Leonardo's Oath assumes that an enlightened society requires the impetus, but not the fundamental ability, to develop itself further, to shape itself by means of the core agreement of scientification. The principle is thus based on a cognitive (shaped) society, which does not create itself subjectively $[10$, p. 167], but instead strives to objectivize the individual knowledge of each individual in order to construct a further development of society as a whole from the sum of these knowledge building blocks (referred to here as a design act). The call of the Leonardo's Oath is that within the framework of engineering science teaching, this ability of design should be:

- active participation (of willingness to contribute),

- authentic emancipation (of wanting to understand the other) and

- complex anticipation (of weighing up findings),

- promoted, precisely because this creative capacity [11] is a prerequisite that engineers must bring to bear so as to at least support the future development of an irrevocably technology-based society.

However, it must also be made clear that it appears from the point of view of the "now" as an educational task that can only be (very) incomplete, because:

- it is indeed apparent that social communities are increasingly moving away from the principle of cognitivist-based (and thus non-radical) constructivism outlined above, as this gives rise to alternative solutions which are not anticipated in their complexity. Instead they are replaced by aversively constructed models which are then discursively irreconcilable and exclude a consensus solution. The resulting effect of not controlling technical and social development can be incorporated into university curricula (and not only in the engineering sciences), but:

- at the same time, this requires a teaching staff who, in addition to their indisputably necessary high level of professional expertise, are able to carry out such reflection work based on actual project work in a moderating capacity and who have also developed a high level of understanding of how to expose ideology-burdened thought patterns in such a way that they can be overcome free of animosity on the part of the students [12].

The final conclusion can therefore be summed up as follows. Even the effect that digitalization requires a primarily economic approach instead of a primarily ecological one does not solve the fundamental problem. Even participation in the shaping of society with a view to a socio-ecological balance is confronted with the duality between the ethical necessity of shaping $[1 ; 13]$ 
and the real impossibility of actually achieving a balance. But it is precisely engineering students who develop their rational thought structures as a vocational profession who must nevertheless be enabled to formulate unbiased alternatives as elements of discourse.

\section{References}

1. FEANI position paper on Code of Conduct: Ethics and Conduct of Professional Engineers, approved by the FEANI GENERAL Assembly on 29 September 2006. Available at: https://www. feani.org/sites/default/files/Position\%20Paper\%20Code\%20of\%20Conduct\%20Ethics.pdf (accessed 10.12.2020)

2. Dreher, R. (2015). A Benchmark for Curricula in Engineering Education: The Leonardic Oath. In: 2015 International Conference on Interactive Collaborative Learning (ICL). Florence, pp. 713-715, doi: 10.1109/ICL.2015.7318117

3. Crawley, E.F., Malmquist, J., Östlund, S., Brodeur, D. R., Edström, K. (2014). Retbinking Engineering Education. The CDIO-Approach. Springer International Publishing, 311 p., doi: 10.1007/978-3-319-05561-9

4. Dreher, R. (2016). Der Leonardische Eid als Paradigma Ingenieurwissenschaftlicher Curricula: In: Kammasch, G; Dreher, R. Wie viel (Grundlagen) Wissen braucht technische Bildung? Wege zur technischen Bildung. Siegen, pp. 78-85, ISBN 978-3-9818728-0-4

5. Dreher, R., Gornov, A.O., Kondratyev, V.V. (2019). Concept of the Natural Structure of Engineering Education and the Code of Professional Ethics of an Engineer. Vysshee obrazovanie v Rossii= Higher Education in Russia. Vol. 28, no. 1, pp. 76-85.

6. Vgl. hierzu die Auffassung von Kath, dass die Basisaktivität Leben-Gestalten vor allem technisch dominiert ist; Kath, F.M. (2002). Noch einmal Prüfen und Werten beim "Arbeiten mit Projekten”. In: Dreher, R., Spöttl, G. (Eds.). Arbeiten mit Projekten. Ein Ansatz für mebr Selbständigkeit beim Lernen. Bremen, pp. 121-129, ISBN 3-934836-57-7

7. Rademacher, F.-J. (2006). Leuchtturm in schwerer See. In: Politische Ökologie. Re-Vision. Nachdenken über ökologische Vordenker. Wien, pp. 46-49

8. Rauner, F., Heinemann, L. (2011). Begründungsrahmen für ein Kompetenzmodell beruflicher Bildung. In: Rauner, F. et.al. (Eds.). Messen beruflicher Kompetnezen. Band III: Drei Jabre KOMET-Testerfabrtung. Münster, pp. 17-50. ISBN: 978-3-643-11238-5

9. Quadrado, J.C., Zaitseva, K.K. (2019). New Pedagogical Approaches to Induce Sustainable Development Goals. Vysshee obrazovanie v Rossii =Higher Education in Russia. Vol. 28, no. 3, pp. 50-56.

10. von Glasersfeld, E. (1991). Fiktion und Realität aus der Perspektive des radikalen Konstruktivismus. In: Rötzer, F., Weibel, P. Straegien des Scheins: Kunst, Computer, Medien. München, pp. 161-175. ISBN-10: 3924963533

11. Prikhodko, V., Sazonova, Z., Chechetkina, N. (2005): "Yin" and "Yan" of Engineering Creativity. Vysshee obrazovanie v Rossii=Higher Education in Russia. No. 11, pp. 21-26.

12. Quadrado, J.C., Zaitseva, K.K. Engineering Education: Interdisciplinarity in Global Teams [Electronic resources]. In: 45th SEFI Annual Conference 2017: Education Excellence for Sustainability: Proceedings, pp. 954-961. Available at: https://www.sefi.be/wp-content/uploads/ SEFI_2017_PROCEEDINGS.pdf (accessed 10.12.2020)

13. Code of Ethics for Engineers. National Society of Professional Engineers. Available at: https:// www.nspe.org/sites/default/files/resources/pdfs/Ethics/CodeofEthics/NSPECodeofEthicsforEngineers.pdf (accessed 10.12.2020) 